\title{
○土橋麻理、飯田慎也、原島秀吉、際田弘志 徳島大学薬学部薬剤学教室
}

Simulation study on the optimum conditions of liposomes for antitumor effect of doxorubicin and its experimental validation

Mari TSUCHIHASHI, Shinya IIDA, Hideyoshi HARASHIMA, and Hiroshi KIWADA

Facuity of Pharmaceutical Sciences, The University of Tokushima, 1-78-1, Sho-machi, Tokushima 770, Japan

【目的】リポソームをドラッグキャリアーとして 抗腄癔効果の增強と副作用の軽減の試みが行われ ており、欧米においてはすでに臨床でも用いられ ている。しかしながら、リポソームの最適な条件 の定量的予测と評価はなされていない。そこで、 我々はモデル薬物としてタイプ I 型の抗癌凨ドキ ソルビシン (DOX) を選択し、殺細胞モデルを導 入した生理学的モデを用いて、リポソームある いは癌細胞の性質等を変化させたときの DOX 封 入リポソームの抗䡤燩効果への影響をシミュレー ションにより定量的に予測することを試みだ”。 また、リポソームの脂質組成やコレステロール含 量を変元ることで、in vivo における DOX の放出 速度 (krel) の異なるリポソームを調製し、k rel に よる抗腫場効果の違いをサバイバル実験により定 量的に評価し、シミュレーションの妥当性を梚討 することを目的とした。

【方法】モテルの構築 : 生理学的モデルに殺細胞 モデル2) をリンクさせ (Fig.1)、リポソームの細絗 内皮系への取り込名速度定数である $\mathrm{kRES}$ と、リ

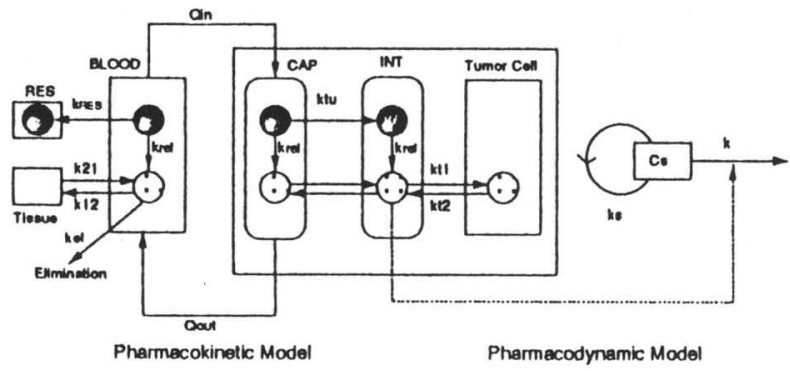

Fig.1 Pharmacokinetic/pharmacodynamic model of liposomal doxorubicin.
リポソームからの薬物放出速度定数である krel を 変化させたときの癌細胞数をシミュレートした。 シミュレーションにおける抗埂准効果の判定基準 は、癌の增殖を最も速くかつ最も強く抑制するも のが最適であると考えた。

リポソームの調製：リポソームの脂質組成は PEG-DSPE : HEPC (又はEPC) $:$ CHO $=5: 60: 35$

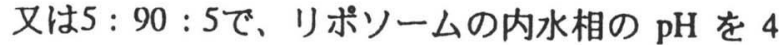
又は 2 とし、DOX は pH-gradient 法引により封入 した。粒子径は100-200 nmに調整した。 in vivo における krel の測定：DOX 封入リポソー ムをCDF1 マウスに尾静注後、脂質 $\left({ }^{3}[\mathrm{H}]\right.$ cholesteryl hexadecyl ether) と DOX の血清中濃度 を測定した。Lipid、DOX 濃度それぞれの血清中 濃度 $(\% \mathrm{dose} / \mathrm{ml})$ 推移に対し、1または2コンパー トメントモデルでフィッティングを行い、モー メント理論に基づき、kRESを求めた。次に、 DOX と lipid の濃度の比を latency として表し、 同様にして krel を算出した。
A) $\mathrm{KRES}=0.006$

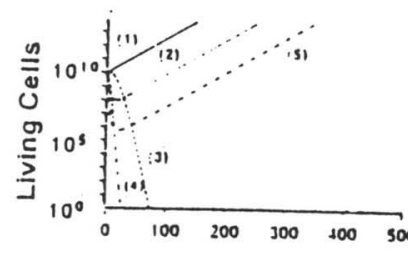

B) $\mathrm{kPES}=0.06$

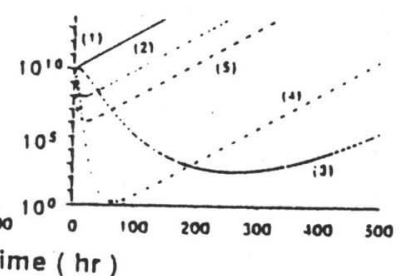

Fig.2 Effect of alteration of kRES and krel on the antitumoreffect of liposomal doxorubicin. The lines which represent $\mathrm{krel}$ is descrived below : (1) Control, (2) Free DOX, (3) krel=0.006, (4) $\mathrm{krel}=0.06,(5) \mathrm{kreil}=0.6$ 


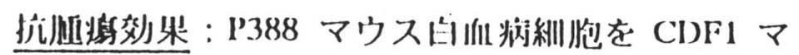
ウス腹腔に移植し、DOX 封入リポソームを DOX 浱度 $6 \mathrm{mg} / \mathrm{kg}$ で尾静脈より投与し、その生存 111 線 より抗廆煌效果を测定した。

【結果及び考察】シミュレーションにより抗厘 搗效果の促進に、III中滞留性のリポソームが有 用で、 krel には $0.06\left(\mathrm{hr}^{-1}\right)$ という最適な値が存在

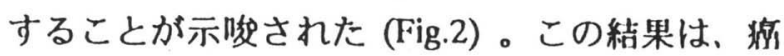

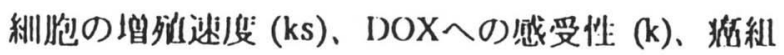

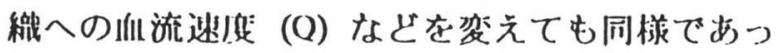
た”。次に、この実験的恰証を行うために、in vivo での $\mathrm{krel}$ の测定とその制御を行った。リポ ソームの牌質組成を変化させ krel を求めたとこ ろ、HEPC より EPCが、また CHO 含量を下げ ることで krel は大きくなり、 krel の㫼御が可能

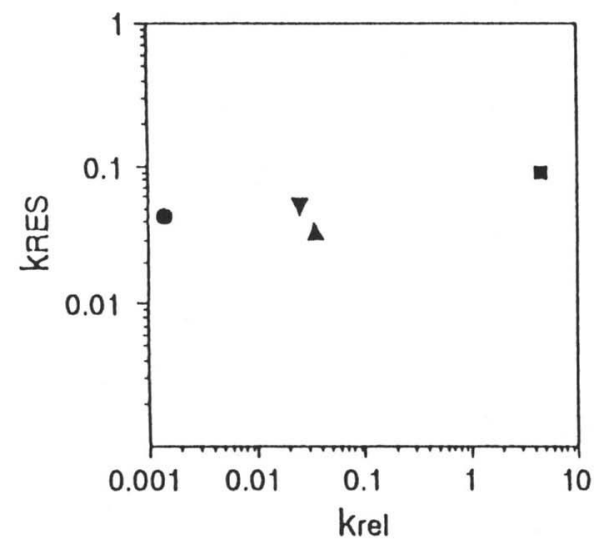

Fig.3 Effect of liposome composition and inner $\mathrm{pH}$ on the rate of drug release from liposomes.

- $\mathrm{PEG} / \mathrm{HEPC} / \mathrm{CHO}=5 / 60 / 35(\mathrm{pH} 4)$, $\triangle \cdot \mathrm{PEG} / \mathrm{EPC} / \mathrm{CHO}=5 / 60 /$ $35(\mathrm{pH} 4), \nabla \mathrm{PEG} / \mathrm{EPC} / \mathrm{CHO}=5 / 60 / 35(\mathrm{pH} 2), \mathrm{PEG} / \mathrm{EPC} /$ $\mathrm{CHO}=5 / 90 / 5(\mathrm{pH} 4)$
であった (Fig.3)。また、これらのリポソームは いずれも同程度の血中洲留性を示した。さらに、 䁘なる krel のリポソームを川いてサパイバル垁 験を行ったところ、 $\mathrm{krel}$ の最も遅い PEG : HEPC $: \mathrm{CHO}=5: 60: 35(\mathrm{pH} 4)$ リポソームにおいて、 最も抗媑燩效果が增強され (Fig.4)、 krel は 0.06 $\left(\mathrm{hr}{ }^{-1}\right)$ が最適というシミュレーション絬果とは㷠 なった。

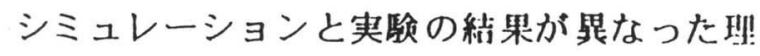

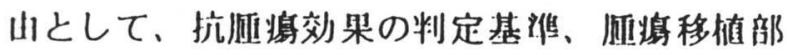

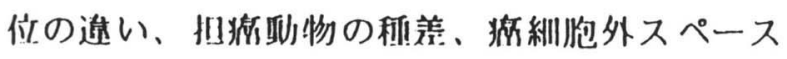

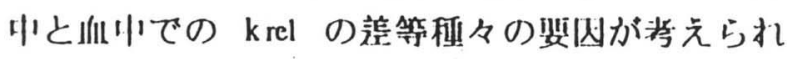
る。現在サバイバル実験と同条非での、マウス 腹腔癌でのシミュレーションを行い、この原因 について検討中である。

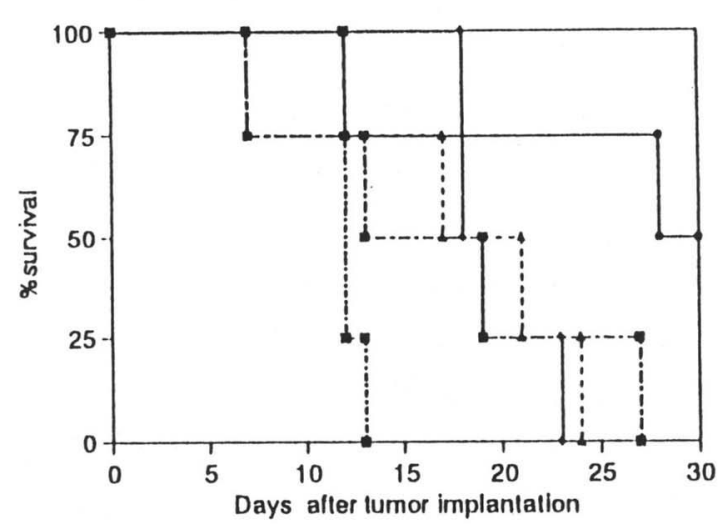

Fig.4 Survival curves for CDF1 mice inoculated i.p. with $\mathrm{P} 388$ cells treated by i.v. injection of DOX in liposomes with different krel.

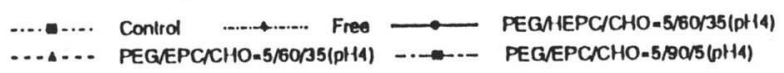

【Abstruct】 To estimate quantitative information of antitumor effect, simulations were performed by the physiological model linked with a cell kill kinetic model. Antitumor effect of liposomal DOX was increased with the increase of blood circulating time. There was the optimum rate of drug release (krel) from long circulating liposomes. To examine this model, we prepared liposomes with different krel, which can be made by changing lipid composition such as HEPC, EPC and CHO. Antitumor effect of liposomal DOX with different krel was evaluated by survival experiments. Liposomes with the lowest krel showed the highest antitumor effect. This result was different from our prediciton based on the computer simulations, which regured some corrections of our model.

\section{【References】}

1) 飯由慎也ら、第11国日本楽物動態学会（全㳄、10月、1996作）

2) S. Ozawa, et al. Cancer Research , 49, 3823-3828 (1989)

3) L. D. Mayer, et al. Biochim. Biophys. Acta , 1025, 143-151 (1990) 